\title{
Analysis of Determinants of Development Imports in Indonesia
}

\author{
Malem Ateta Br. Purba ${ }^{1}$, Muhammad Fitri Rahmadana ${ }^{2}$, Fitrawaty ${ }^{3}$ \\ ${ }^{1,2,3}$ Universitas Negeri Medan, Indonesia \\ malemateta1409@gmail.com
}

\begin{abstract}
Indonesia is known as a developing country which industrial production has not been sustainable to the local demand. This is reflected in Indonesia's dependence on other countries in terms of consumer goods, raw and auxiliary materials as well as capital goods. Indonesia carries out import activities because most domestic products have not been able to compete with foreign products, and there is a sense of grandeur for the people when they are able to buy goods from abroad. The purpose of this study is to analyze the effect of gross domestic product (GDP), foreign exchange reserves, exchange rates and inflation on imports in Indonesia in 2000 - 2019. The method of analysis in this study uses the Error Correction Model (ECM). The estimation results show that in the short term, the variable gross domestic product (GDP), foreign exchange reserves and inflation have a positive and significant effect on imports in Indonesia, while in the long run, all variables have a significant and significant effect on imports in Indonesia. In this case, the support of the government and producers by providing good quality production will greatly assist in the development of the domestic industry, so that the Indonesian people turn to domestic products again.
\end{abstract}

\section{Keywords}

imports, gross domestic product (GDP); foreign exchange reserves, exchange rates, inflation; error correction model (EOM)

\section{Introduction}

The value of Indonesia's imports cannot be separated from the influence of domestic demand for consumer goods, imports of raw and auxiliary materials as well as capital goods whose supply has not been fully fulfilled by domestic industries. One of the goods imported by Indonesia is consumer goods, raw materials and capital goods.

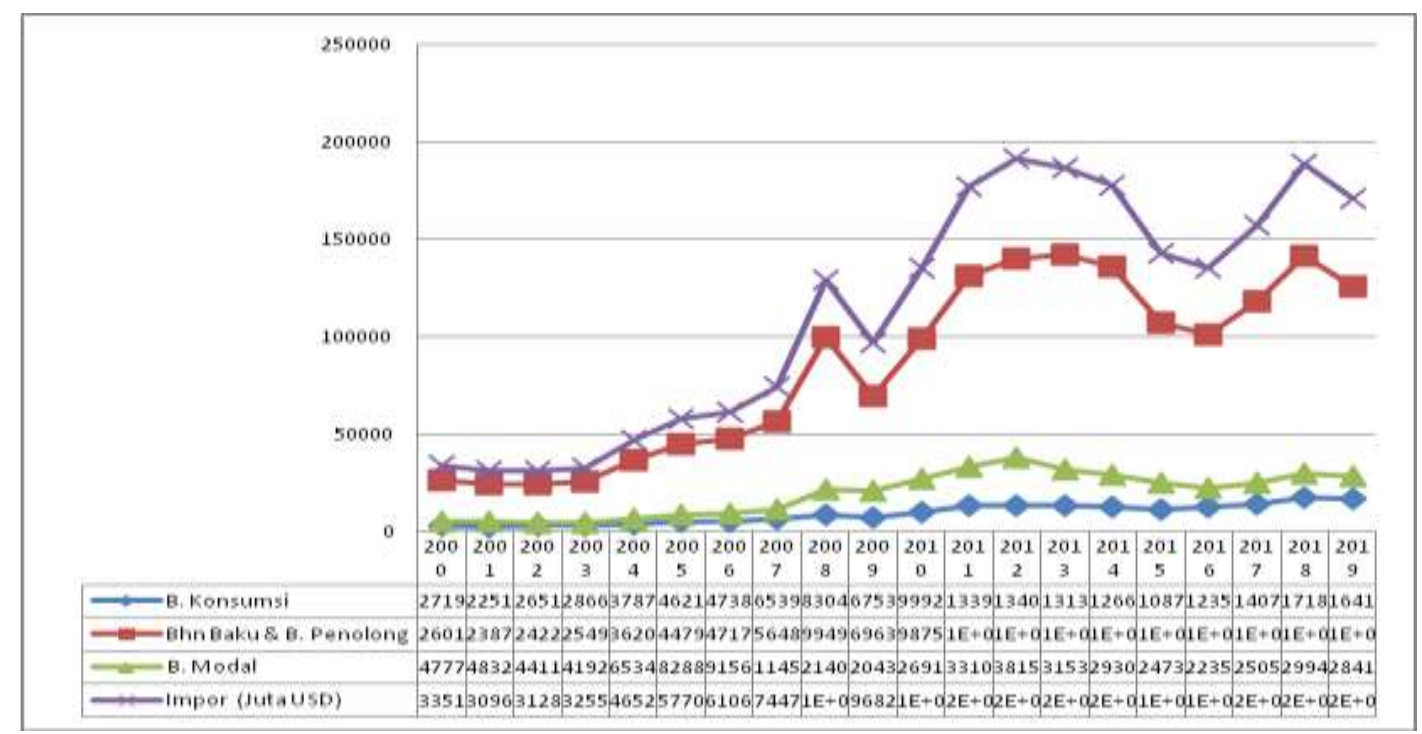

Figure 1. Imports by type of goods 2000-2019 (million USD) 
From the statistical data above, it can be seen that Indonesia's imports from 2000 to 2019 have generally increased. Although it seems to have decreased in 2001 in total 30,962.1 million USD, but in the following year imports increased to 31,288.9 million USD. This is due to the improvement in Indonesia's macroeconomic conditions. From 2002 to 2008, Indonesia's imports continued to increase and seemed to decrease drastically, reaching 96,829.20 million USD in 2009, which previously was in the position of $129,197.30$ million USD. This is because in that year Indonesia was affected by the world demand crisis caused by declining income in a number of developed countries, such as the United States, the European Union and Japan. In the following year it has increased in the following years, although in 2013 it decreased again in a row until 2016. In 2013 there was a decrease to 186.628.70million USD due to the result of weakening world demand caused by the crisis in the European Union and the unstable economy in the United States. It can also be seen that in 2017 and 2018, imports have increased to188,711.30 million USD. This was due to an increase in non-oil and gas imports by USD 457 million or around $3.65 \%$, although oil and gas imports fell by USD 418 million or around $16.31 \%$. The decline in oil and gas imports was triggered by the decline in all oil and gas components, namely crude oil, oil and gas products, as well as the trade war between the United States and China which triggered a weakening of the world economy which had implications for Indonesia. And in 2019, Indonesia's imports decreased by 5.62\% from 188,711.30 million USD to 170,727.40 million USD. This occurs because all categories of goods use, both consumer goods, raw materials or auxiliary goods and capital goods, both experienced a decline compared to the previous year period, respectively 4.51 percent, 11.07 percent, and 5.13 percent.

The real Gross Domestic Product (real GDP) of any country is a measure of the value of economic output adjusted for price changes (inflation/deflation) in that country. It is the sum of the consumer spending, the investment made by industry, the excess of exports over imports, and the government spending. When an economy is going through a persistent inflation, the GDP increases, this does not actually reflect the true growth in an economy. Hence, the rate of inflation must be subtracted from the GDP to get the real growth percentage, called the real GDP. (Ademuyiwa and Adetunji, 2019)

According to Sukirno (2004), imports greatly affect a country's economic growth because it is a component that is taken into account in measuring total gross domestic income. The effect of gross domestic income on imports in a country is quite large. When gross domestic income increases, people's purchasing power will also increase, causing imports to increase as well. Imports have a positive relationship with gross domestic income, which means that the higher the gross domestic income of a country, the higher the imports the country will make.

Imports are related to economic growth. When economic growth increases, domestic demand will increase. So that to meet domestic needs, imports from other countries are carried out. The greater the import, the greater the demand for foreign currency which causes the exchange rate to tend to increase in price, so that the domestic currency weakens against foreign currencies. Because the purchase of imported goods increases, the foreign exchange reserves also decrease because the foreign exchange reserves function to finance export and import activities, pay off foreign debts, and intervene in the foreign exchange market to stabilize the exchange rate (Leonufna et al., 2006).

Foreign exchange reserves have an effect on imports, where when the foreign exchange reserves and the needs of a country increase without being accompanied by an increase in domestic productivity, then imports will occur. Foreign exchange reserves are needed to finance imports and pay off foreign debts. 
The country of Indonesia is one of the countries where the availability of foreign reserves is small. This caused the Indonesian state to be unable to stabilize the exchange rate and payments when it experienced a deficit in the balance of payments and a drop in the rupiah exchange rate. The development of Indonesia's foreign exchange reserves from 2000 to 2019, during the last 20 years Indonesia's foreign exchange reserves continued to increase except in 2001, 2005, 2008, 2013, 2015 and 2018. Decrease in foreign exchange reserves can affect import volume, because the availability of foreign exchange reserves becomes an influence big on export and import activities. These limitations will make it difficult for Indonesia to carry out import activities because Indonesia has to re-budget,

The higher the value of the foreign currency against the domestic currency, the lower the value of the domestic currency (depreciation) against the foreign currency and vice versa if the value of the foreign currency decreases against the domestic currency (appreciation) it will result in an increase in the domestic currency. country. If a country with an exchange rate is in a depreciating state, its imports will decrease, while if it is in a state of appreciation, its imports will increase.

Imports of Indonesian goods are not only affected by income, but also by changes in inflation. Keynes's theory explains that inflation occurs as a result of the existence of a part of society whose life cycle exceeds its economic limit or excess demand, so that the price of domestic goods increases and imports of goods rise along with the reduced supply of goods in the market. This shows that inflation has an effect on Indonesia's imports.

\section{Review of Literature}

\subsection{International Trade}

International trade is defined as a trade transaction between one country's economic subjects and another country's subjects, both regarding goods and services. As for the economic subject in question is the population consisting of ordinary citizens, export companies, import companies, industrial companies, state companies and government departments which can be seen from the trade balance (Sobri, 2000). International trade is a process of exchange based on the voluntary will of each party who must have the freedom to determine whether he wants to make an exchange or not. In general, international trade is an activity involving supply (export) and demand (import) between countries. When carrying out export activities, the country receives foreign exchange for payment. This foreign exchange will be used to finance import activities carried out. One country's exports are imports for other countries, and vice versa (Boediono, 2015).

According to Putong (2013), the factors that cause international trade are:

a. In order to obtain goods or resources that cannot be produced domestically.

b. Obtaining goods that can actually be produced domestically, but the quality does not meet the requirements.

c. Obtaining more modern technology in order to empower domestic natural resources.

d. Expanding the market for products produced in the country.

e. Benefit from specialization, such as absolute advantage, competitive advantage and competitive advantage. 


\subsection{Import}

According to Imam (2013), import activities are an activity of public consumption of goods from abroad. If a country opens international trade and becomes an importer of a good, the domestic producers of the goods will be disadvantaged, while the domestic consumers of the goods will benefit. The opening of international trade will benefit the country concerned as a whole, because the benefits obtained exceed the losses (Mankiw, 2006).

The imports of a country are determined by several factors, including the country's competitiveness and foreign exchange rates. However, the main determinant of imports is the income of the people within the country itself. The higher the people's income, the higher the imports they will do (Sukirno, 2004). Based on the considerations, the import function is expressed in the equation:

$$
\begin{aligned}
& \mathrm{M}=\mathrm{mY} \\
& \mathrm{M}=\mathrm{Mo}+\mathrm{mY}
\end{aligned}
$$

Where $\mathrm{M}$ is the import value, Mo is an autonomous import that is not determined by national income and $\mathrm{m}$ shows the marginal propensity to import, which is the ratio of added value to imports to the increase in national income. Marginal propensity to import is a number that shows how much increase in import value is due to an increase in national income by one unit of money (one rupiah). The import function is expressed as a line or curve showing the relationship between imports and national income. The import function moves to the right, because the nature of imports is that the higher the national income, the greater the import activity (Sukirno, 2004).

\subsection{Gross Domestic Product}

Gross domestic product is an important indicator to determine the development of the economy in a country in a certain period. According to Mankiw (2007), gross domestic product is the market value of all goods produced by a country and within a certain period. Gross domestic product is also defined as the national product which is realized by domestic production factors (owned by citizens and foreigners) in a country.

According to Mankiw (2007), the objective of gross domestic product is to summarize economic activity in a certain amount of money over a certain period of time. Gross domestic product is a statistic that is often considered as the best measure to assess the performance of the economy. There are two ways of looking at statistics, the first by looking at the gross domestic product as the sum of the income of everyone in the economy and the second, by looking at the gross domestic product as the sum spent on the output of goods and services in the economy. Both methods show that gross domestic product is the best measure in assessing the performance of the economy (Mankiw, 2006).

\subsection{Foreign Exchange Reserves}

Foreign exchange reserves are defined as foreign assets controlled by the monetary authority to finance balance of payments imbalances and are useful for maintaining exchange rate stability and can be used to finance deficits in the balance of payments (Arunachalan, 2010). Foreign exchange reserves are part of national savings, where the size of the growth in foreign exchange reserves is a signal to global financial markets regarding the country's credit worthness and the credibility of monetary policy.

Foreign exchange reserves are very influential on the economy of a country because the amount of foreign exchange reserves can be used as a strong monetary indicator for the weakness of a country's economic fundamentals to assess the level of 
resilience in facing economic crises, if the higher the value of foreign exchange reserves owned by a country, it will be resilient in the face of an economic crisis ( Dianita and Zuhroh, 2018).

\subsection{Exchange Rate}

The exchange rate is the price of the domestic currency of one unit of foreign currency (Salvatore, 2014). Thus, if the domestic currency is rupiah and the foreign currency is US Dollar, then the rupiah exchange rate can be defined as the amount of rupiah that must be exchanged to obtain one unit of US Dollar.

According to Anwary (2011), the exchange rate is the exchange between two different currencies, which is a comparison of the value or price between the two currencies. This comparison of values is often referred to as the exchange rate. Exchange rates usually fluctuate, changes in exchange rates can take the form of depreciation and appreciation. The depreciation of the rupiah against the US dollar is a decrease in the price of the US dollar against the rupiah. Meanwhile, the appreciation of the rupiah against the US dollar is the increase in the rupiah against the US dollar.

\subsection{Inflation}

Inflation is an increase in the prices of goods (commodities) in general which is caused by the unsynchronized program of the commodity procurement system (production, pricing, printing money and so on) in the level of income owned by the community (Putong, 2010).

Since both inflation and economic growth are not a new concept rather their relationships are waited still now as a debatable issue among macro-economists, policy makers, policy analysts, politicians and even the population itself by giving their own analysis by conduct a research and assumption based on the trend as before. (Wollie, 2018)

However, if the increase in the price of only one or two goods is not called inflation, unless the increase is widespread and causes a large increase in the price of other goods. The increase in the price of goods does not have to be at the same percentage level.

Inflation is a process of increasing the price of goods in general that goes on continuously, not just for one item and not for a moment. An increase in the price of one or two goods alone cannot be called inflation unless the increase extends (or results in price increases) for other goods (Nanga, 2005). Inflation arising from the regional or global economic crisis has greatly affected the imports of two countries. Inflation causes an increase in the price of goods and causes a decrease in people's purchasing power. The price of imported goods also affects imports. This is due to the country's dependence on goods that the country cannot fulfill itself, which causes it to import. Thus, the price of imported goods greatly affects imports. Inflation can also cause changes in the distribution patterns of people's income and wealth. Inflation seems to be a tax for someone and a subsidy for others, inflation is nothing but a tax on cash balances held by the public because money is increasingly worthless (Boediono, 2015). 


\section{Research Methods}

The scope of this study focuses on variables that affect imports, namely gross domestic product, foreign exchange reserves, exchange rates, and inflation. The time period used is 20 years from 2000 to 2019 . The data used in this study are secondary data which is time series data, namely data collected from 2000 to 2019.

Useful steps or procedures to solve problems from start to finish are as follows.

1. The first stage carried out in this research is to begin with formulating the right problem in accordance with the problem that is the background of this research, after that it is continued at the second stage.

2. The next stage is to collect time series data regarding imports, gross domestic product, foreign exchange reserves, exchange rates and inflation in Indonesia from 2000 to 2019. From this data, we want to know whether or not there is an effect of the independent variable on the dependent variable.

3. Determine the regression model, so that it is known that the dependent variable and each independent variable are linearly or non-linearly related. Determination of the regression model in this study using a scatter gram, MWD test, and BM test.

4. The fourth stage is to perform a stationary test using the unit root test with the ADF.

a. If it is stationary at the level, a VAR model will be carried out which is called VAR at the level (VAR in level), then proceed to step 12.

b. If the data is not stationary at the level level, then continue the differentiation process to get stationary data, this is called the degree of integration test.

5. The degree of integration test is carried out until all the data is stationary at the same differentiation, if it is still not stationary at the same differentiation, it is retested with the degree of integration test at the next level until it is stationary.

6. When the data is stationary at the same differentiation, a cointegration test is carried out to determine whether the residuals in the regression are stationary.

a. If the data is not cointegrated or the residual value of research data that has been integrated to the same degree is not stationary at the level, it can be said that there is no long-term relationship between the independent variable and the dependent variable, so the next step is to use the VAR model at the differentiation level. (VAR in diference) after that go to step number 12.

b. If the data is co-integrated or the residual value of research data that has been integrated at the same degree is stationary at the level, it means that there is a longterm relationship between the two variables. After that go to the 7th rare.

7. After being co-integrated, it means that there is a long-term relationship between the independent variable and the dependent variable which is likely to have imbalance in the short term. Therefore, to correct imbalances in the short term, an error correction model (ECM) is used. After the results of the ECM analysis are obtained, the model can be identified in the short term, then proceed to the 8th stage.

8. The 8th stage carried out in this research is to analyze the results of the model in the long and short term. The analysis is carried out by analyzing the $\mathrm{R} 2$ value, testing the hypothesis of the independent variables simultaneously to determine whether or not the variables have an influence on the forward variable. In addition to testing simultaneously, hypothesis testing is also carried out partially for each independent variable. Partial testing is carried out to determine whether or not there is an effect of each of these variables on the dependent variable. If long-term and short-term analysis of the results of the model has been done, then the next step is to the 9th stage. 
9. The 9th stage is carried out, namely performing the classical assumption test. The classical assumption tests carried out at this stage are the normality test, autocoleration free, and homodecasticity of the residuals, as well as the multicollinearity free test between independent variables that affect the dependent variable.

a. If the classical assumption test is not fulfilled in accordance with the BLUE estimator criteria, then handling is carried out on the unfulfilled calcic assumption test, but for the multicollinearity free test, if it is not met, treatment is not necessary. This is because without multicollinearity handling, we still get BLUE estimators. If the handling of unfulfilled assumptions has been completed, the next research stage is like the 9th stage.

b. If all the classical assumption tests required to meet the BLUE estimators have been fulfilled, then proceed to the 10th stage.

10. The next research stage is to interpret the regression model in the long and short term that is obtained after fulfilling the classical assumption test, then proceed to the 11th stage.

11. The 11th stage is to formulate conclusions that are in accordance with the formulation of the problem in this study.

12. Done.

\section{Results and Discussion}

The error correction model (Error Correction Model) can explain the behavior of the short-term and long-term effects of the independent variables on the dependent variable. In this study, the resulting ECT (Error Correction Term) value is -0.871043 with a t-statistic value of -4.910478 and the probability is $0.0003<\alpha=5 \%$. The value of the ECT (Error Correction Term) coefficient is negative and statistically significant, it means that the ECM Domowitz-El Badawi Error Correction Model used in this study is valid. The value of the ECT (Error Correction Term) coefficient can affect how sooner or later the equilibrium can be reached again. The ECT coefficient (Error Correction Term) value of -0.871043 means that the difference between the annual actual value and the equilibrium value is 0 .

\subsection{The Influence of Gross Domestic Product on Imports in Indonesia}

The regression results in the short term show that gross domestic product has a significant positive effect on the development of Indonesian imports, where the gross domestic product variable has a coefficient of 1.722201 which means that when the gross domestic product increases by $1 \%$ it will result in an increase in Indonesian imports by $1.72 \%$, ceteris paribus. This is in accordance with the economic theory that the relationship between Indonesia's gross domestic product and imports is positive. With the t-statistic $2.724996>$ t-table 2.131, it can be concluded that the gross domestic product variable in the short term has a significant effect on imports in Indonesia.

The long-term regression results show that gross domestic product has a significant positive effect on the development of Indonesia's imports. Where the gross domestic product variable has a coefficient of 0.781288 which means that when the gross domestic product increases by $1 \%$ it will result in an increase in economic growth of $0.78 \%$, ceteris paribus. This is in accordance with the economic theory that the relationship between gross domestic product and imports is positive. With the t-statistic 2.563400> t-table 2.131, it can be concluded that the gross domestic product variable in the long run has a significant effect on imports in Indonesia. 
An increase in gross domestic product in a country will be related to the development of imports that occur in that country. This is because a country that has a national income that increases every year will increase the country's ability to engage in international trade activities. In addition, an increase in gross domestic product also results in changes to consumption patterns. Where national income greatly affects the consumption pattern of the population. As a result of increased consumption patterns in developing countries, the total imports will tend to increase. This is because the productivity in the country has not been able to meet all domestic needs (Nanga, 2005).

Gross domestic product also causes an increase in the level of welfare, but it is followed by changes in the tastes of the people who are increasingly fond of imported products. This is because people believe that the use of imported products is a symbol of one's splendor, so that their taste immediately increases imports in line with the increase in gross domestic product. Nopirin (2009) argues that the higher the level of gross domestic product, the more likely it is to import. This means that it can be concluded that imports and the level of income or gross domestic product have a positive relationship.

The results of this study are in line with research conducted by Kuswantoro and Gita (2006) which states that gross domestic product both in the short and long term has a positive and significant effect on Indonesia's non-oil and gas imports. And it is also supported by research by Surbakti and Yabes (2020) which states that gross domestic product has a positive and significant effect on Indonesian imports.

\subsection{The Effect of Foreign Exchange Reserves on Imports in Indonesia}

The regression results in the short term show that foreign exchange reserves have a significant positive effect on the development of Indonesian imports, where the foreign exchange reserve variable has a coefficient of 0.929308 , which means that when foreign exchange reserves increase by $1 \%$ it will result in an increase in Indonesian imports by $0.93 \%$, ceteris paribus. This is in accordance with the economic theory that the relationship between foreign exchange reserves and imports is positive. With the t-statistic 2.937948> t-table 2.131, it can be concluded that the short-term foreign exchange reserve variable has a significant effect on imports in Indonesia.

The long-term regression results show that foreign exchange reserves have a positive and significant effect on the development of Indonesia's imports. Where the foreign exchange reserve variable has a coefficient of 0.686658 which means that when foreign exchange reserves increase by $1 \%$ it will result in an increase in Indonesian imports by $0.69 \%$. This is in accordance with the economic theory which states that the relationship between foreign exchange reserves and imports is positive. With the t-statistic 2.307662> t-table 2.131, it can be concluded that the variable of foreign exchange reserves in the long term has a significant effect on imports in Indonesia.

Foreign exchange reserves are related to the development of imports in Indonesia. Where the foreign exchange reserves have a positive effect on increasing imports. The position of a country's foreign exchange reserves is usually declared safe if it is sufficient for imports for a period of at least three months. If the foreign exchange reserves held are not sufficient for three months of import, then this condition is considered vulnerable. The thin stock of foreign exchange in a country can create economic difficulties for the country concerned. Not only will this country find it difficult to import the goods it needs from abroad, but it can also degrade the credibility of its currency. 


\subsection{The Effect of Exchange Rates on Imports in Indonesia}

The short-term regression results show that the exchange rate variable has a positive and insignificant effect on the development of Indonesian imports, where the exchange rate variable has a coefficient of 0.391899 which means that when the exchange rate increases by $1 \%$ it will result in an increase in Indonesian imports by $0.39 \%$. This is not in accordance with the economic theory which states that the relationship between the rupiah exchange rate (exchange rate) and imports is negative, while the results of short-term research show that the relationship between the rupiah exchange rate and imports is positive. With t-statistic $0.824227<\mathrm{t}$-table 2.131 , it can be concluded that the variable rupiah exchange rate (exchange rate) in the short term does not have a significant effect on imports in Indonesia.

In the short term, the results show that the exchange rate variable does not have a negative and insignificant effect on Indonesian imports. This conclusion is not in accordance with the research hypothesis. Based on the results of research conducted by Imam (2013), imports of consumer goods in Indonesia are not determined based on the level of exchange rate developments. In addition, the continued increase in the dollar exchange rate due to the unstable economic situation has made domestic industries vulnerable to bankruptcy, especially industries that rely on foreign raw materials for their production. Then this will affect domestic production which continues to decrease so that the government must cover the shortfall by importing.

The long-term regression results show that the exchange rate variable has a negative and significant effect on the development of Indonesia's imports. Where the exchange rate variable has a coefficient of -1.025685 which means that when the exchange rate increases by $1 \%$ it will result in a decrease in Indonesian imports by $1.03 \%$, ceteris paribus. This is in accordance with the economic theory that the relationship between the rupiah exchange rate (exchange rate) and imports is negative. With t-statistic -2.474752> t-table 2.131, it can be concluded that the variable rupiah exchange rate (exchange rate) in the long run has a significant effect on imports in Indonesia.

In the long term, the results show that the exchange rate variable has a negative and significant effect on Indonesian imports. The negative effect of the exchange rate on Indonesian imports could occur because if the rupiah depreciates (the rupiah weakens), the prices of imported goods are relatively more expensive than the prices of domestic goods so that import demand will decline. Conversely, if the rupiah appreciates (the rupiah strengthens), then the prices of imported goods are relatively cheaper than the prices of domestic goods so that import demand will increase.

\subsection{The Influence of Inflation on Imports in Indonesia}

The short-term regression results show that inflation has a significant positive effect on the development of Indonesian imports, where the inflation variable has a coefficient of 0.026728 which means that when inflation increases by $1 \%$ it will result in an increase in Indonesian imports by $0.03 \%$, ceteris paribus. This is in accordance with the economic theory that the relationship between inflation and imports is positive. With the t-statistic 3.914949> t-table 2.131, it can be concluded that the inflation variable in the short term has a significant effect on imports in Indonesia.

The long-term regression results show that inflation has a positive and significant effect on the development of Indonesia's imports. Where the inflation variable has a coefficient of 0.043220 which means that when inflation increases by $1 \%$ it will result in an increase in Indonesian imports by $0.04 \%$, ceteris paribus. This is in accordance with the economic theory that the relationship between inflation and imports is positive. With the t- 
statistic 3.148237> t-table 2.131, it can be concluded that the inflation variable in the long run has a significant effect on imports in Indonesia.

The regression coefficient of the inflation variable in both the short and long term is positive and in accordance with theoretical expectations or in accordance with economic criteria. Thus the hypothesis which states that inflation has a positive and significant effect on Indonesian imports is acceptable.

Based on the cosh-push inflation theory according to Nanga (2005), inflation that occurs due to a rapid increase in production costs compared to productivity and efficiency, which causes companies to reduce their supply of goods and services to the market. In other words, inflation is inflation that occurs as a result of restrictions on the supply of one or more resources, or inflation that often occurs when the price of one or more resources increases or increases. As a result of this inflation, exports will decline, which means that inflation has a positive effect on imports.

If inflation occurs in Indonesia, then for domestic consumers the prices of imported goods will be relatively cheaper than the prices of domestic goods. The difference in the relative prices of these goods will be able to change consumer behavior to prefer buying imported goods so that the demand for Indonesian imports will increase. Siregar (2010) states that an increase in the price of goods will encourage imports to obtain goods or services that are cheaper with better quality.

In terms of numbers, it turns out that the increase in imports as a result of the increase in inflation in Indonesia is quite large. Therefore, the government's policy to maintain low and stable inflation can be an alternative that can reduce Indonesia's imports which at the same time is also expected to improve Indonesia's trade balance position.

\section{Conclusion}

Based on the results of the analysis and discussion that have been stated, the following conclusions can be drawn:

1. The development of imports in Indonesia from year to year continues to increase, although in certain years some have experienced a decline. However, overall, Indonesia's imports continue to increase. This is because most of the types of goods imported are raw materials and capital goods, which are indispensable for the production process, in order to increase output.

2. Gross domestic product, foreign exchange reserves, rupiah exchange rate (exchange rate) and inflation affect imports in Indonesia individually (partially) and collectively (simultaneously) in the long term in 2000-2019. Whereas in the short term, the variables that affect individually (partially) and collectively (simultaneously) are gross domestic product, foreign exchange reserves and inflation. Meanwhile, the rupiah exchange rate (exchange rate) variable in the short term has no effect on Indonesia's imports.

3 . From the regression results, it is found that gross domestic product in the short term has a coefficient of 1.336697 which means that when the gross domestic product increases by $1 \%$ it will result in an increase in Indonesian imports by $1.34 \%$. While the long-term regression results of the gross domestic product variable have a coefficient of 0.683684 which means that when the gross domestic product increases by $1 \%$ it will result in an increase in economic growth of $0.68 \%$. This is in accordance with economic theory which states that the relationship between gross domestic product and imports is positive.

4. The short-term regression results of the foreign exchange reserves variable has a coefficient of 0.945728 , which means that when foreign exchange reserves increase by $1 \%$, it will result in an increase in Indonesian imports by $0.94 \%$. Meanwhile, in the long 
term, foreign exchange reserves have a coefficient of 0.678851 which means that when foreign exchange reserves increase by $1 \%$, it will result in an increase in Indonesia's imports by $0.68 \%$. This shows that in the short term and in the long term, the foreign exchange reserve variable has a significant effect on imports in Indonesia

5. The short-term regression results of the Rupiah exchange rate variable against the US Dollar (exchange rate) has a coefficient of 0.387547 which means that when the exchange rate increases by $1 \%$ it will result in an increase in Indonesian imports by $0.39 \%$. This is not in accordance with economic theory and in the short term, the rupiah exchange rate does not have a significant relationship to imports in Indonesia. Whereas in the long term the exchange rate has a coefficient of -1.063173 which means that when the exchange rate increases by $1 \%$ it will result in a decrease in Indonesia's imports by $1.06 \%$. This suggests that in the long run the exchange rate has a significant effect on Indonesia's imports.

6. The short-term regression results for the inflation variable have a coefficient of 0.032225 which means that when inflation increases by $1 \%$ it will result in an increase in Indonesian imports by $0.03 \%$. Whereas in the long term, inflation has a coefficient of 0.049205 which means that when inflation increases by $1 \%$ it will result in an increase in Indonesian imports by $0.05 \%$. This shows that in the short term and in the long term, the inflation variable has a significant effect on imports in Indonesia.

\section{References}

Ademuyiwa and Adetunji. (2019). Impact of Some Economic Variables on the Real Gross Domestic Product of Nigeria. Budapest International Research and Critics InstituteJournal (BIRCI-Journal). P. 12-19

Amir, M. S. (2007). Ekspor Impor Teori dan Penerapannya. Jakarta: Lembaga Manajemen PPM.

Arunachalan. (2010). Foreign Exchange Reserves in India and China. African Journal of Marketing Management, 2 (4): 69-79.

Boediono. (2015). Ekonomi Internasional. Yogyakarta: BPFE.

Dianita, D. and Zuhroh, I. (2018). Analisa Cadangan Devisa Indonesia Tahun 1990-2016. Jurnal Ilmu Ekonomi, 2 (1): 119-131.

Imam, A. (2013). Faktor-Faktor yang Mempengaruhi Impor Barang Konsumsi di Indonesia. Jurnal ekonomi Pembangunan, 1(2).

Leonufna, L., Robby, and Mandeij D. (2016). Analisis Pengaruh Neraca Pembayaran Internasional Terhadap Tingkat Kurs Rupiah/Dolar AS Melalui Cadangan Devisa dalam Sistem Kurs Mengambang Bebas di Indonesia Periode 1998.1 Sampai 2014.4. Jurnal Berkala Ilmiah Efisiensi, 16 (02).

Mankiw, N.G. (2006). Makroekonomi. Jakarta: Erlangga.

Mankiw, N.G. (2006). Principles of Economic. Pengantar Ekonomi Makro. Edisi Ketiga. Alih Bahasa Chriswan Sungkono. Jakarta: Salemba Empat.

Mankiw, N.G. (2007). Makroekonomi. Jakarta: Erlangga.

Nanga, M. (2005). Makroekonomi, Teori, Masalah dan Kebijakan. Jakarta: PT. Raja Grafindo Persada.

Nopirin. (2009). Ekonomi Internasional. Edisi Ketiga. Yogyakarta: BPFE-Yogyakarta.

Putong, I. (2010). Ekonomi: Pengantar Mikro dan Makro Edisi 4. Jakarta: Mitra Wacana Media.

Salvatore, D. (2014). Ekonomi Internasional. Jakarta: Salemba Empat. 
Siregar, A. (2010). Analisis Faktor-Faktor yang Mempengaruhi Impor di Indonesia. Tesis Universitas Sumatera Utara.

Sukirno, S. (2004). Teori Pengantar Makro Ekonomi. Jakarta: PT. Raja Grafindo Perkasa.

Sukirno, S. (2007). Makroekonomi Modern. Jakarta: Rajawali Press.

Surbakti, M. and Yabes O.G. (2020). Analisis Pengaruh Produk Domestik Bruto, Tingkat Inflasi, dan Nilai Tukar Rupiah atas US Dollar Terhadap Impor Indonesia Periode 2010.Q1-2007.Q4. Jurnal Visi Pendidikan, 1 (1): 1-21.

Wollie, G. (2018). The Relationship between Inflation and Economic Growth in Ethiopia. Budapest International Research and Critics Institute-Journal (BIRCI-Journal). P. 264-271. 